\title{
PENGARUH METODE MENGHAFAL DAN MOTIVASI BELAJAR SISWA TERHADAP PRESTASI MENGHAFAL AL-QUR'AN
}

\author{
Mustafa \\ Institut PTIQ Jakarta \\ Email: musthofaakhi@gmail.com
}

\begin{abstract}
ABSTRAK
Penelitian ini bertujuan untuk mengetahui dan menguji data-data empirik terkait pengaruh metode menghafal dan motivasi belajar siswa terhadap prestasi menghafal Al-Qur'an secara terpisah maupun simulat. Dalam penelitian ini, penulis menggunakan metode survei dengan pendekatan korelasional dan regresional terhadap data-data kuantitatif yang diperoleh dari objek penelitian yaitu siswa kelas sembilan (9) SMP IT Darul Qur'an Bogor. Sampel penelitian ini adalah sebanyak 109 responden dari total 150 populasi kelas sembilan (9) SMP pada semester ganjil tahun ajaran 2018-2019. Pengumpulan data dilakukan dengan menggunakan teknik angket/kuesioner, observasi, dan dokumentasi. Jenis analisis yang digunakan adalah analisis korelasi dan regresi yang dijabarkan secara deskriptif. Hasil dari penelitian ini adalah: Pertama, terdapat pengaruh yang positif dan signifikan antara metode menghafal dengan prestasi menghafal Al-Qur'an siswa SMP IT Darul Qur'an dengan koefisien korelasi (r) sebesar 0,458 dan koefisien determinasi $\mathrm{R}^{2}(R$ square) sebesar $0,9 \%$. Arah pengaruh ditunjukan dengan persamaan $\mathrm{Y}=87,325+0,001 \mathrm{X}_{1}$, berarti bahwa setiap peningkatan satu unit metode menghafal akan mempengaruhi peningkatan skor prestasi menghafal Al-Qur'an 0,027.Kedua, terdapat pengaruh yang positif dan signifikan antara motivasi belajar siswa dengan prestasi menghafal Al-Qur'an siswa SMP IT Darul Qur'an dengan koefisien korelasi (r) sebesar 0,112 ${ }^{\mathrm{a}}$ dan koefisien determinasi $\mathrm{R}^{2}(R$ square $)$ sebesar $1,2 \%$. Arah pengaruh ditunjukan dengan persamaan $\hat{Y}=81,226+0,060 \mathrm{X}_{2}$. yang berarti bahwa setiap peningkatan satu unit metode menghafal dan motivasi belajar siswa akan mempengaruhi peningkatan skor prestasi menghafal Al-Qur'an sebesar 0,060.Ketiga, terdapat pengaruh metode menghafal dan motivasi belajar siswa terhadap prestasi menghafal Al-Qur'an dengan koefisien korelasi atau $0,671 \times 0,671=0,125$ ) yang mengandung makna bahwa $12,5 \%$ variabilitas variabel prestasi menghafal AlQur'an dapat dijelaskan oleh metode menghafal dan motivasi belajar siswa. Hal ini dapat disimpulkan bahwa metode menghafal $\left(\mathrm{X}_{1}\right)$ dan motivasi belajar siswa $\left(\mathrm{X}_{2}\right)$ secara bersama-sama memberikan pengaruh terhadap prestasi menghafal AlQur'an (Y) sebesar 12,5\% sedangkan sisanya 87,5\% $(100 \%-12,5 \%=87,5 \%)$ ditentukan oleh faktor-faktor yang lainnya.
\end{abstract}

Kata kunci: metode menghafal, motivasi belajar, prestasi menghafal 


\begin{abstract}
This research aims to determine and examine empirical data related to the influence of memorization methods and student learning motivation on the achievement of memorizing the Qur'an separately or simulatively. In this research, the authors used a survey method with a correlational and regression approach to quantitative data obtained from the object of research, namely ninth grade students (9) of SMP IT Darul Qur'an Bogor. The sample of this research was 109 respondents from a total of 150 population classes nine (9) junior high school in the odd semester of the 2018-2019 academic year. Data collection is done by using questionnaire/questionnaire, observation, and documentation techniques. The type of analysis used is correlation analysis and descriptive regression analysis. The results of this research are:First, there are a positive and significant influence between the memorization method and the achievement of memorizing the Al-Qur'an students of SMP IT Darul Quran with a correlation coefficient (r) of 0,458 and a coefficient of determination $\mathrm{R} 2$ (R square) of $0,9 \%$.. The direction of influence is shown by the equation $\hat{\mathrm{Y}}=87,325+0,001 \mathrm{X}_{1}$, meaning that each increase in one unit of memorization method will affect the increase in the AlQur'an memorization achievement score 0,027.Second, there are a positive and significant influence between students' learning motivation and the achievement of memorizing the Al-Qur'an students of SMP IT Darul Quran with a correlation coefficient (r) of $0,112^{\mathrm{a}}$ and a coefficient of determination of R2 (R square) of $1,2 \%$. The direction of influence is shown by the equation $\hat{Y}=81,226+0,060 \mathrm{X}_{2}$. which means that each increase in one unit memorization method and student learning motivation will affect the increase in Al-Qur'an memorization achievement score of 0,060.Third, there are the effect of memorizing methods and student learning motivation on the achievement of memorizing the Qur'an with a correlation coefficient or $0,671 \times 0,671=0,125$ which implies that $12,5 \%$ of the variability of the memorizing achievement of the Qur'an can be explained by the method of memorizing and students' motivation. It can be concluded that the memorization method (X1) and student learning motivation (X2) together have an influence on the achievement of memorizing the Qur'an (Y) by $21.3 \%$ while the remaining $87,5 \%(100 \%-12,5 \%=87,5 \%)$ determined by other factors.
\end{abstract}

Keywords: memorization method, learning motivation, memorization achievement 


\section{PENDAHULUAN}

Menghafal Al-Qur'an adalah suatu perbuatan yang sangat mulia dan terpuji. Sebab orang yang menghafal Al-Qur'an merupakan salah satu dari keluarga Allah (Ahlullah) dimuka bumi. Itulah sebabnya, tidak mudah dalam menghafal Al-Qur'an. ${ }^{1}$ Seseorang yang ingin menghafal Al-Qur'an hendaknya membaca Al-Qur'an dengan benar terlebih dahulu. ${ }^{2}$ Dan dianjurkan agar sang penghafal lebih dahulu lancar dalam membaca Al-Qur'an, sebab kelancaran saat membacanya niscaya akan cepat dalam menghafal Al-Qur'an.

Menghafal Al-Qur'an merupakan pekerjaan yang cenderung sulit dari pada membaca dan memahaminya. Hal ini terjadi karena selain memiliki lembaran yang sangat banyak, Al-Qur'an memiliki nuansa bahasa yang relatif sulit untuk difahami dan memliki banyak ayat-ayat yang mirip (mutashabihat). Menghafal Al-Qur'an membutuhkan proses yang begitu lama, ketekunan dan kesungguhan sangat diperlukan sekali usaha keras, ingatan yang kuat serta minat dan motivasi yang besar yang disesuaikan dengan kemampuan masing-masing orang. Sehingga tidak jarang banyak sekali para siswa/santri yang berhenti di tengah jalan sebelum menyelesaikan hafalan sebanyak 30 juz. Hal tersebut dikarenakan lemahnya tekad, kurangnya motivasi dari dalam diri dan dari orang terdekat, dan yang paling pokok menjadi problematika siswa dalam menghafal Al-Qur'an biasanya yaitu malas dalam melakukan muroja'ah yaitu mengulangkembali hafalan yang sudah dihafal sehingga beban dalam menjaga hafalan terasa berat sekali karena terlalu banyak yang telah lupa hingga akhirnya berhenti menjadi pilihan bagi mereka yang merasa sudah tidak mampu lagi untuk menghafal.

Oleh karena itu dalam mencapai tujuan untuk menghafal Al-Qur'an atau untuk mencapai prestasi menghafal Al-Qur'an membutuhkan jangka waktu tertentu dalam prosesnya membutuhkan motivator yang sekaligus sebagai pembimbing, serta metode-metode yang pas dalam menghafal, dan untuk membantu calon hafidz dalam menyelsaikan hafalannya sangat diperlukan adanya bimbingan dan pembina/musyrif secara terus menerus untuk mengontrol sjauh mana tingkat hafalan atau prestasi dalam menghafal yang sudah dicapai oleh siswa atau santri. Pembinaan terhadap calon hafidz biasanya dilakukan oleh lembaga-lembaga pendidikan agama yang mengkhususkan diri dalam bidatang Al-Qur'an dan juga pondok pesantren.

Pesantren terpadu Darul Qur'an Mulia adalah salah satu lembaga dari sekian banyak lembaga yang salah satu kekhususanya adalah menghafal alQur`an. Lembaga tersebut memilki keunggulan yang sangat signifikan. Salah satu keunggulan yang dimilki pesantren terpadu Darul Qur`an Mulia adalah metode Pengajaran Al-Qur`an.

pesantren terpadu Darul Qur`an Mulia mampu menghasilkan siswa-siswa yang berkualitas, khususnya dalam menghafal al-Qur`an. bahkan banyak diantara siswa-siswanya yang berprestasi baik ditingkat nasional ataupun internasional.

Lahirnya Generasi Qur'ani tentu saja didukung dengan interaksi yang komprehensif terhadap Al-Qur'an dalam bentuk: Tilawah, Tahsin, Tafhim, dan Tahfizh nilai-nilai yang ada di dalamnya. Sehingga muncul kecintaan terhadap AlQur'an. Keempat bentuk interaksi terhadap Al-Qur'an tersebut tidak dapat

\footnotetext{
${ }^{1}$ Wiwi Alawiyah Wahid, Cara Cepat Bisa Menghafal Al-Qur'an, Jogjakarta: Diva Press, 2012, hlm. 13

${ }^{2}$ Ahmad Salim Badwilan, Panduan CepatMenghafal Al-Qur'an, Jogjakarta, Diva Press, 2009, hlm. 85
} 
dipisahkan satu sama lain. Ketiadaan pada salah satunya meniscayakan adanya bagian yang tidak sempurna dari tujuan Al-Qur'an diturunkan kepada umat manusia.

Hal tersebut membuat penulis tertarik untuk mengkaji dalam sebuah karya ilmiah. Sehingga akan menjadi sebuah model untuk dicontoh oleh lembagalembaga lain, khususnya dalam sistem pengajaran dalam menghafal Al-Qur`an.

Setiap lembaga pendidikan mempunyai metode tersendiri dalam membina dan mengembangkan kemampuan menghafal Qur'an, pun dengan masing-masing individu dalam satu pesantren punya cara tersendiri untuk menghafal Qur'an, selain metode masing-masing santri juga mempunyai motivasi yang berbeda dan beragam, sehingga penelitian ini difokuskan korelasi antara Metode Menghafal Qur'an dan Motivasi Belajar terhadap Capaian Hafalan Santri dengan mengambil judul penelitian PENGARUH METODE MENGHAFAL DAN MOTIVASI BELAJAR SISWA TERHADAP PRESTASI MENGHAFAL QUR'AN.

\section{PEMBAHASAN}

Menghafal pada dasarnya merupakan bentuk atau bagian dari proses mengingat. Karena mengingat sendiri mempunyai pengertian menyerap atau meletakan pengetahuan dengan jalan pengecaman secara aktif. ${ }^{3}$ Ingatan dapat dibagi kedalam tiga tahapan utama : pengkodean (menerima informasi), menyimpan (menyimpan informasi), dan pengambilan (menemuka informasi) dari tempat penyimpanan saat kita memerlukannya.Termasuk keistimewaan al-Qur'an adalah menjadi satu-satunya kitab suci yang dihafalkan oleh banyak manusia di bumi ini. Tak satupun kitab suci yang dihafalkan seperti al-Qur'an. al-Qur'an diingat di dalam hati dan pikiran para penghafalnya. Hal ini karena al-Qur'an terjaga bahasanya dan telah terjamin oleh Allah akan selalu dijaga serta dipelihara, firman Allah dalam Qur'an Surah Al-Hijr/15:9, sebagai berikut:

Sesungguhnya Kami-lah yang menurunkan Al Quran, dan Sesungguhnya Kami benar-benar memeliharanya.

Ayat ini merupakan garansi dari Allah bahwa dia akan Meskipun Allah menggaransikan Al-Qur'an tetapi kita tetap harus berusaha menjaganya dengan cara menghafalkannya. Allah juga berpesan agar kita ikut andil dalam memelihara al-Qur'an, maksudnya ikut andil dengan cara menghafal al-Qur'an.Faktor-faktor yang mempengaruhi prestasi menghafal :Faktor pendukung,Persiapan individu: Kecerdasan dan ingatan yang kuat,Usia yang cocok/. Faktor Penghambat:Pertama, tidak mampu membaca Al-Qur'an dengan baik Kedua, tidak mampu mengatur waktu, Ketiga, adanya ayat-ayat yang serupa, ayat-ayat mutasyabihat banyak sekali terdapat dalam Al- Qur'an, Keempat, pengulangan yang sedikit, jika penghafal dalam proses menghafal Al-Qur'an merasa kesusahan dalam merekam ayat-ayat yang sedang dihafal, atau ketika menyetor hafalan tibatiba bacaannya tidak lancar padahal sebelumnya merasa sudah lancar dan betulbetul hafal, hal itu menandakan pengulangan terhadap ayat yang dihafalnya masih kurang. ${ }^{4}$ Kelima, tempat dan lingkungan kurang kondusif, tempat dan lingkungan menghafal yang tidak kondusip seperti tempat kerja, tempat keramaian dan sebagainya, akan memecahkan konsentrasi penghafal sehingga akan mengalami

\footnotetext{
${ }^{3}$ Syaiful Sagala, Konsep dan Makna Pembelajaran, Bandung : Alfabeta, 2003, hlm. 128

${ }^{4}$ Abdul Aziz Abdul Rauf, Kiat Sukses Menjadi Hafidz Qur'an Da'iyah, Bandung: Pt Syaamil Cipta Media, Cet. IV, 2004, hlm. 87
} 
hambatan dalam menghafal Al-Qur'an. Maka tempat yang bias membantu konsentrasi menghafal hendaknya dipilih oleh para penghafal AlQur'an. Keenam, tidak ada pembimbing, keberadaan seorang pembimbing dalam menghafal Al-Qur'an sangat penting. Pembimbing akan selalu memberikan semangat kepada para penghafal. Jadi para penghafal yang tanpa pembimbing akan mengalami hambatan dalam menghafal Al-Qur'an yang cukup patal. ${ }^{6}$

Prestasi menghafal Al-Qur'an (Y) sebagai variabel terikat. Berdasarkan uraian diatas, dapat disimpulkan bahwa indikatornya sebagai berikut: ${ }^{7}$ Dapat menghafal dengan lancar. Dapat menghafal sesuai dengan makhrajnya. Dapat menghafal sesuai dengan harakat (tanda baca). Dapat menghafal sesuai dengan kaidah ilmu tajwid. Pencapaian hafalan yang maksimalSetiap kali ujian kenaikan juz mendapatkan nilai maksimal.Ada beberapa kriteria yang digunakan untuk menilai kemampuan menghafal Al Qur'an, secara umum dapat dijelaskan bahwa kriteria kemampuan menghafal al-Quran adalah :Menguasai makharijul huruf, yaitu keluarnya bunyi huruf dari mulut.Menguasai tajwid, antara lain hukum nun mati atau tanwin ( idzhar halqi, ikhfa haqiqi, idgham bighunnah, idgam bila ghunnah, iqlab), hukum mim sukun (idgham mimi, idzhar syafawi, ikhfa syafawi) ghunnah musyaddadah, mad, lafal jalalah, qalqalah, al qamariyah dan syamsiyah, dan hukum tajwid lainya.Benar dan lancer Tartil yaitu membaca dengan pelan-pelan per huruf.Dari kriteria di atas peneliti menggunakan tiga indikator yaitu: Kelancaran

Anak dikatakan mampu menghafal Al-Qur'an apabila ia dapat berbicara dan membaca dengan fasih. Tingkat kefasihan dalam membaca Al-Qur'an ada empat macam, sebagaimana yang telah disepakati oleh ahli tajwid, antara lain: Pertama, tahqiq yaitu menghafal Al-Qur'an dengan menempatkan hak-hak huruf (makharijul huruf, sifatul huruf, mad, qosr, tarqiq, tahkim, dsb.) yang semestinya, sambil mencermati/meresapi arti dan maknanya bagi yang telah mampu. Kedua, tartil menghafal Al-Qur'an dengan berlahan-lahan (tidak tergesa-gesa) sambil mencermati/meresapi arti dan makna bagi yang telah mampu. Ketiga, tadwir Membaca Al-Qur'an dengan sedang, antara cepat dan perlahan-lahan. Keempat, $h a d r$ Membaca alquran dengan cepat Keempat cara membaca atau menghafal Al Qur'an tersebut wajib menggunakan tajwid dengan menyesuaikan bacaanya (tahqiq, tartil, tadwir, dan hadr )..Macam-Macam Metode Menghafal

Tabel 2.1

Metode Menghafal al-Qur'an dan Karakteristik Utamanya

\begin{tabular}{|l|l|l|}
\hline No & Metode & \multicolumn{1}{|c|}{ Karakteristik Utama } \\
\hline 1 & Tahfidz & $\begin{array}{l}\text { Menghafal secara mandiri, uji kemampuan secara privat, } \\
\text { diberi tugas di luar kegiatan belajar }\end{array}$ \\
\hline 2 & Wahdah & $\begin{array}{l}\text { Ada contoh bacaaan dari guru, menghafal per ayat atau } \\
\text { beberapa ayat, uji kemampuan bertahap sesuai materi } \\
\text { hafalan, diberi tugas di luar kegiatan belajar, bimbingan } \\
\text { privat terhadap kesulitan }\end{array}$ \\
\hline 3 & Kitabah & Menulis ayat kemudian dihafalkan, uji kemampuan privat \\
\hline
\end{tabular}

\footnotetext{
${ }^{5}$ Yahya Abdul F. Az-Zawawi, Revolusi Menghafal menghafal Al-Qur'an, jakarta: Rineka Cipta, Jurnal. Vol. 5 No. 1, 2010, hlm, 77-78.

${ }^{6}$ Abdul Aziz Abdul Rauf, Kiat Sukses Menjadi Hafidz Qur'an Da'iyah, Bandung: PT. Syaamil Cipta Media, Cet. IV, 2004, hlm. 89

${ }^{7}$ Achmad Lutfi, Pembelajaran Al-Qur'an Hadits, Jakarta: Direktorat Jenderal Pendidikan Islam Kementerian Agama, 2012, hlm. 171-172.
} 


\begin{tabular}{|l|l|l|}
\hline 4 & $\begin{array}{l}\text { Wahdah } \\
+ \\
\text { Kitabah }\end{array}$ & $\begin{array}{l}\text { Menghafal ayat kemudian hafalan ditulis pada kertas yang } \\
\text { disiapkan, uji kemampuan berkelompok atau privat, diberi } \\
\text { tugas di luar kegiatan belajar }\end{array}$ \\
\hline 5 & Jama' & $\begin{array}{l}\text { Menghafal bersama dipimpin guru, diulang-ulang, tanpa } \\
\text { evaluasi kemampuan }\end{array}$ \\
\hline 6 & Talaqqi & $\begin{array}{l}\text { Belajar privat tanpa mengutamakan lembaga pendidikan, } \\
\text { menghafal langsung uji kemampuan, diberi tugas di luar } \\
\text { kegiatan belajar }\end{array}$ \\
\hline 7 & Jibril & $\begin{array}{l}\text { Siswa menirukan bacaan guru dan disertai penjelasan } \\
\text { makna ayat, uji kemampuan privat atau berkelompok }\end{array}$ \\
\hline 9 & Tsyarat & $\begin{array}{l}\text { Pemberian materi hafalan diikuti gerakan tangan, mimik, } \\
\text { dsb., uji kemampuan privat, diberi tugas di luar kegiatan } \\
\text { belajar }\end{array}$ \\
\hline 10 & Sorogan & $\begin{array}{l}\text { Mengulang-ulang materi secara bersamaan hingga masuk } \\
\text { dalam memori hafalan, uji kemampuan privat atau } \\
\text { berkelompok, diberi tugas di luar kegiatan belajar }\end{array}$ \\
\hline $\begin{array}{l}\text { Menghafal mandiri, setor hafalan pada guru pembimbing, } \\
\text { uji kemampuan langsung, diberi tugas di luar kegiatan } \\
\text { belajar }\end{array}$ \\
\hline
\end{tabular}

Indikator metode menghafal

Kalau kita merujuk kepada sistem pembelajaran klasik, terdapat sebuah ungkapan yang menyatakan bahwa "At Thariqatu Ahammu Minal Maddah, Wal Ustadzu Ahammu Minat Tariqah, Wa Ruhul Ustadzu Ahammu Min Kulli Syaiin" Arti dari kaidah di atas adalah bahwa "Metode lebih utama daripada materi, dan guru lebih utama daripada metode, serta ruh (semangat) guru lebih utama dari segalanya".

\section{Motivasi Belajar Siswa}

Kata motivasi berasal dari kata motif yang dalam psikologi berarti tenaga yang mendorong seseorang berbuat sesuatu. Motif dapat dikatakan sebagai daya penggerak dari dalam dan di dalam subjek untuk melakukan aktivitas-aktivitas tertentu demi mencapai suatu tujuan. ${ }^{8}$

Jika diaplikasikan dalam belajar, jika kita lihat motif yang mendasari perbuatan belajar yang kita lakukan itu mungkin berbeda-beda. Pembentukan tenaga-tenaga yang disebut motivasi. ${ }^{9}$ Sedangkan menurut Martin Handoko, pengertian dari motivasi adalah suatu tenaga atau faktor yang terdapat didalam diri manusia, yang menimbulkan, mengarahkan atau mengorganisasikan tingkah lakunya. ${ }^{10}$ Pada dasarnya motivasi adalah usaha yang di dasari untuk mengarahkan dan menjaga tingkah laku seseorang agar ia terdorong untuk bertindak melakukan sesuatu sehingga mencapai hasil atau tujuan tertentu. Sehingga motivasi dan belajar merupakan dua hal yang saling mempengaruhi. Belajar merupakan perubahan tingkath laku secara relatif permanen dan secara potensial terjadi

${ }^{8}$ A.M. Sardiman, Interaksi dan Motifasi Belajar Mengajar, Jakarta: PT Raja Grafindo Persada, 2005, hal. 73

${ }^{9}$ Buchori M, Psikologi Pendidikan, Jakarta: Rineka Cipta, 1991, hlm. 42

${ }^{10}$ Martin Handoko, Motivasi Daya Penggerak Tingkah Laku, Yogyakarta: Kanisius, 1992, hlm. 9 
sebagai hasil dari praktik atau penguatan yang dilandasi tujuan untuk mencapai tujuan tertentu. ${ }^{11}$

Dalam kamus Besar Bahasa Indonesia (KBBI) dicantumkan bahwa $:{ }^{12}$ Motivasi belajar dapat timbul karena faktor interinsik, berupa hasrat dan keinginan berhasil dan dorongan kebutuhan belajar, harapan akan cita-cita. Sedangkan faktor eksterinsiknya adalah adanya penghargaan lingkungan belajar yang kondusif, dan kegiatan belajar yang menarik. Tetapi harus diingat kedua faktor tersebut disebabkan oleh rangsangan tertentu, sehingga seseorang berkeinginan untuk melakukan aktifitas belajar yang lebih giat dan semangat. Hakikat motivasi belajar adalah dorongan internal dan eksternal pada siswa-siswi yang sedang belajar untuk mengadakan perubahan tingkah laku, pada umumnya dengan beberapa indikator atau unsur yang mendukung. ${ }^{13}$ dalam belajar dapat diklasifikasikan sebagai berikut:Adanya cita-cita dan kemampuan dalam belajar Kondisi siswa dan lingkungan. Adanya kegiatan yang menarik dalam belajar Macam-Macam Motivasi Belajar Siswa

1) Motivasi Intrinstik

Motivasi intrinstik adalah penghargaan internal yang disarankan seseorang jika mengerjakan tugas. ${ }^{14}$ Atau perbuatan individu yang benar-benar didasari oleh suatu dorongan (motif) yang tidak dipengaruhi dari lingkungan. ${ }^{15}$ Apabila seseorang memiliki motivasi tersebut dalam dirinya maka ia akan sadar akan melakukan suatu kegiatan yang tidak memerlukan motivasi dari luar dirinya.

2) Motivasi Ekstrinsik

Motivasi ekstrinsik pada dasarnya merupakan tingkah laku yang digerakan oleh kakuatan eksternal individu. ${ }^{16}$ Motivasi ekstrinsik merupakan daya penggerak yang dapat menambah kekuatan dalam menghafal Al-Qur'an, sehingga tujuan yang diinginkan dapat tercapai. Motivasi ini meliputi :Pertama Orang tua .Motif ini menunjukkan kepada gejala instrinsik, yakni menyangkut kepuasan individual. Kepuasan individual yang berada di dalam diri manudia dan biasanya berwujud proses dan produk mental. Jenis motif seperti ini adalah sangat primer dalam kegiatan belajar, terutama yang berkaitan dengan pengembangan intelektual. Teori ERG Aldelfer berpendapat bahwa terdapat tiga kebutuhan dalam motivasi karyawan. Adapun tiga kebutuhan tersebut adalah sebagai berikut: ${ }^{17}$ Pertama Existence (eksistensi), dalam hal ini memberikan persyaratan eksistensi material dasar.Kedua Relatedness (hubungan) yaitu hasrat yang dimiliki diorientasikan untuk memlihara hubungan antar pribadi, hasrat social dan status menentukan

\footnotetext{
${ }^{11}$ Hamzah B. Uno, Teori Motivasi dan Pengukurannya, Jakarta: PT Bumi Aksara, 2008, hlm. 23

${ }^{12}$ Poerwadarminta, Kamus Besar Bahasa Indonesia, Jakarta: P.N Balai Pustaka, 1990, hlm. 539 $\operatorname{hlm} .23$

${ }^{13}$ Hamzah B. Uno, Teori Motivasi dan Pengukurannya, Jakarta: PT Bumi Aksara, 2008,

${ }^{14}$ M. Ghufron dan Rini Risnawati S, Teori-Teori Psikologi, Jogjakarta: Ar-Ruzz Media,2010, hlm.84

${ }^{15}$ Hamzah B. Uno, Teori Motivasi dan Pengukurannya, Jakarta: PT bumi Aksara, Cet.IV , 2008 , hlm. 33

${ }^{16}$ M. Ghufron dan Rini Risnawati S, Teori-Teori Psikologi, Jogjakarta: Ar-Ruzz Media, 2010, hlm. 84

${ }^{17}$ Clayton Aldelfer, Existence, Relatednes, and Growth, New York: Free Press 1972, hlm. 
interaksi dengan orang lain.Ketiga Growth (pertumbuhan), yaitu suatu hasrat instrinsik untuk perkembangan pribadi. ${ }^{18}$

\section{Penelitian Terdahulu yang Relevan}

Pertama, tesis yang ditulis oleh Kemas H.M Siddiq Umari yang berjudul faktor-faktor yang mempengaruhi penghafalan Al-Qur'an di Institut Ilmu AlQur'an Jakarta. ${ }^{19}$ Menurutnya ada banyak faktor yang menghambat dalam penghafalan Al-Qur'an bagi santri, faktor-faktor tersebut diantaranya latar belakang para penghafal yang ada, dikarenakan para penghafal tersebut berangkat dari pendidikan umum. Kedua, banyaknya beban sks yang dialami para mahasiswa sehingga berakibat pada sedikitnya waktu untuk menghafal dan memahami Al-Qur'an. Ketiga, latar belakang ekonomi keluarga yang pas-pasan, hal ini mengakibatkan banyak santri yang harus bekerja keras guna memenuhi kebutuhan sehari-harinya.Kedua Tesis yang ditulis oleh Yusuf effendi yang berjudul Nilai dan Tanggung jawab dalam metode pembelajaran tahfizh siswa MAK An-Nur di PP An-Nur Ngrukem Bantul. ${ }^{20}$ Menurutnya aspek nilai tanggung jawab yang muncul pada siswa yang mengikuti program tahfizh di Madrasah Aliyah Pondok Pesantren An-Nur lebih banyak dipengaruhi oleh konteks teologis. Dimana manusia sebagai makhluk individual harus Bertanggung jawab terhadap dirinya (keseimbangan jasmani dan rohani) dan juga bertanggung jawab kepada Tuhan-Nya (sebagai pencipta).

\section{Asumsi, Paradigma, dan Kerangka Penelitian}

Paradigma lama yang sudah berkembang di pandangan masyarakat maupun dunia pendidikan yang menganggap bahwa jika ingin berprestasi, maka siswa atau santri harus diberi perhatian atau motivasi, padahal prestasi atau tidaknya bukan hanya terletak di perhatian ataupun motivasi terhadap siswa atau peserta didik namun masih banyak lagi faktor yang lain. Misalnya faktor dari diri seseorang, diantaranya bakat atau potensi, kepandaian atau intelektualitas, minat, kebiasaan, dan pengalaman. Adapun faktor dari luar diri seseorang diantaranya, faktor keluarga, sekolah, masyarakat atau lingkuangan, sarana dan prasarana, fasilitas, dan gizi.

Penafsiran yang keliru bahwa prestasi menghafal siswa yang rendah karena keterbatasan sumber daya manusia yang dimiliki yayasan atau pendapat bahwa ketidak puasan siswa dipicu oleh rendahnya SDM, tetapi jika dikaji secara mendalam teryata semangat musyrif atau guru jauh lebih besar perannya dan pengaruhnya terhadap prestasi menghafal siswa.

Asumsi bahwa metode menghafal mempunyai pengaruh langsung atas sikap kebiasaan yang diperoleh siswa. Kebiasaan itu ditentukan oleh metode menghafal maupun motivasi belajar melalui kebiasaan musyrif itu sendiri. Oleh karena itu untuk mendapatkan prestasi dalam menghafal maka guru harus memberikan keteladanan atau motivasi yang baik kepada siswa.

Yayasan atau lembaga pendidikan yang mampu membina dan memelihara semangat belajar siswa yang tinggi tentu memperoleh banyak prestasi, yaitu disiplin dalam menghafal, komitmen dan semangat menghafal tinggi, sehingga

\footnotetext{
${ }^{18}$ Stephen P. Robbins, Essentials of Organisational Behavior, New Brunswick, Orentice Hall, 2005, hlm. 171

${ }^{19}$ Kemas H.M. Shiddiq Umari, "Faktor-faktor yang mempengaruhi Penghafalan Alqur'an di Institut Ilmu Al-Qur'an Jakarta, Tesis, Jakarta: Prodi Pendidikan Islam UIN Pasca Sarjana, 2005

${ }^{20}$ Yusuf Effendi, "Nilai dan Tanggungjawab dalam metode pembelajaran tahfizh siswa MAK An-Nur di PP An-Nur Ngrukem Bantul, Tesis Yogyakarta: Prodi Pendidikan Islam Konsentrasi Pendidikan Qur'an Hadits UIN Pasca Sarjana, 2011
} 
tercapainya prestasi, jika semangat meningkat, akan ada korelasi positif terhadap peningkatan prestasi menghafal Al-Qur'an.

Kerangka teori merupakan sebuah sistem konsep abstrak yang mengidentifikasikan adanya hubungan antar variabel-variabel yang hendak diteliti. Komponen utama dalam kerangka penelitian ini terdiri dari satu variabel terikat yaitu Prestasi Menghafal Al-Qur'an (variabel Y) dan dua variabel bebas yaitu Metode Menghafal (variabel $\mathrm{X}_{1}$ ) dan Motivasi Belajar Siswa (variabel $\mathrm{X}_{2}$ ) Selanjutnya kedua variabel tersebut diduga mempunyai hubungan dengan Prestasi Menghafal Al-Qur'an. Hubungan dari kedua variabel bebas (independen) terhadap variabel terikat (dependen) dapat dijelaskan sebagai berikut:

1. Pengaruh metode menghafal $\left(\mathrm{X}_{1}\right)$ terhadap prestasi menghafal Al-Qur'an $(\mathrm{Y})$ Menghafal Al-Qur'an merupakan suatu hal yang sangat berkaitan dengan masalah metode menghafal, dalam prinsipnya para penghafal Al-Qur'an hendaknya memiliki metode yang tepat, menarik, dan nyaman sehingga dalam proses menghafal serta mengulangi hafalan, setidaknya para penghafal AlQur'an mempunyai metode sendiri sehingga metode tersebut bagian dalam proses menghafal, sebelum menghafal siswa mentasmi'kan bacaan yang akan di hafal dan selanjutnya setelah siswa hafal terus disetorkan ke musyrif/guru, setelah siswa selesai menyetorkan hafalan barunya maka akan siswa kan dituntut untuk mengulang kembali hafalan yang sudah dihafal. Dalam hal ini metode menghafal sangat efektif dan efisien dalam menghafal Al-Qur'an maka kemampuan dengan metode menghafal akan menempati salah satu bagian yang paling penting dalam setiap proses penghafalan Al-Qur'an, hal ini tidak lain dan tidak bukan hanyalah untuk meningkatkan kualitas dan prestasi menghafal, baik dari segi bacaan maupun dalam mengajar dan mencapai target-target hafalan yang telah ditentukan. Dengan demikian dapat diduga kemampuan metode menghafal siswa sangat erat pengaruhnya terhadap hafalan Al-Qur'an siswa

2. Pengaruh Motivasi belajar siswa (X2) terhadap Prestasi Menghafal Al-Qur'an (Y)

Hafalan Al-Qur'an siswa dapat dijadikan barometer sudah atau belum tercapainya tujuan pendidikan Al-Qur'an dalam suatu lembaga Tahfizh, dan hafalan Al-Qur'an siswa sangat dipengaruhi oleh bagaimana siswa termotivasi dalam melaksanakan tugas dan kewajibannya, karena motivasi sangat penting dalam pendidikan Al-Qur'an.

Namun pada kenyataannya bahwa siswa belum termotivasi secara optimal dalam melaksanakan tugasnya, dengan kata lain siswa belum memiliki disiplin dan tanggung jawab yang tinggi dalam melaksanakan tugas. Penghafal Al-Qur'an yang menuntutnya untuk bersikap secara istiqomah guna menciptakan kedisiplinan, yang dapat mengurangi kemalasan dan menambah semangat siswa dalam belajar menghafal Al-Qur'an, yang pada akhirnya dapat meningkatkan kemampuan para siswai dalam belajar menghafal Al-Qur'an, sehingga dapat memperoleh hafalan Al-Qur'an yang maksimal.

Dengan demikian dapat diduga motivasi belajar siswa sangat erat pengaruhnya terhadap peningkatan prestasi menghafal Al-Qur'an siswa.

3. Pengaruh metode menghafal (X1) dan Motivasi belajar siswa (X2) terhadap prestasi menghafal Al-Qur'an (Y).

Dalam hal ini metode menghafal dan motivasi belajar siswa ialah satu kesatuan yang tidak dapat dipisahkan antara satu dengan yang lain. Metode menghafal dalam hal menghafal dapat mempermudah dalam menghafal Al- 
Qur'an lebih berkualitas dan tercapainya target-target dalam kegiatan hafalan Al-Qur'an. Motivasi belajar siswa dalam menghafal menimbulkan semangat siswa yang akan sangat berpengaruh kepada siswa dalam menghafal AlQur'an sehingga tercapainya hafalan yang maksimal.

Prestasi menghafal Al-Qur'an mempunyai porsi yang sangat signifikan terhadap kesuksesan seorang siswa maupun lembaga. Prestasi siswa yang tinggi biasanya dimulai bagaimana seorang siswa dapat memperoleh dari metode menghafal yang ia miliki dan termotivasi sehingga mengantarkan siswa kepada puncak kemampuannya. Dengan demikian tentunya akan tercapai hafalan Al-Qur'an yang berkualitas dan berprestasi dari segi bacaan dan tercapai target-target hafalan yang telah ditentukan.

Kerangka berpikir dalam sebuah penelitian digunakan sebagai guiding dalam menentukan arah berpikir dan memudahkan memberikan gambaran atas teoriteori yang diuraikan serta masing-masing hubungannya. Kerangka berpikir meliputi pengaruh metode menghafal dan motivasi belajar siswa terhadap prestasi menghafal Al-Qur'an Siswa SMP IT Darul Quran. Oleh karena itu berdasarkan uraian diatas, maka kerangka pemikiran teoritis dalam penelitian ini dapat digambarkan dalam kerangka tabel di bawah ini.

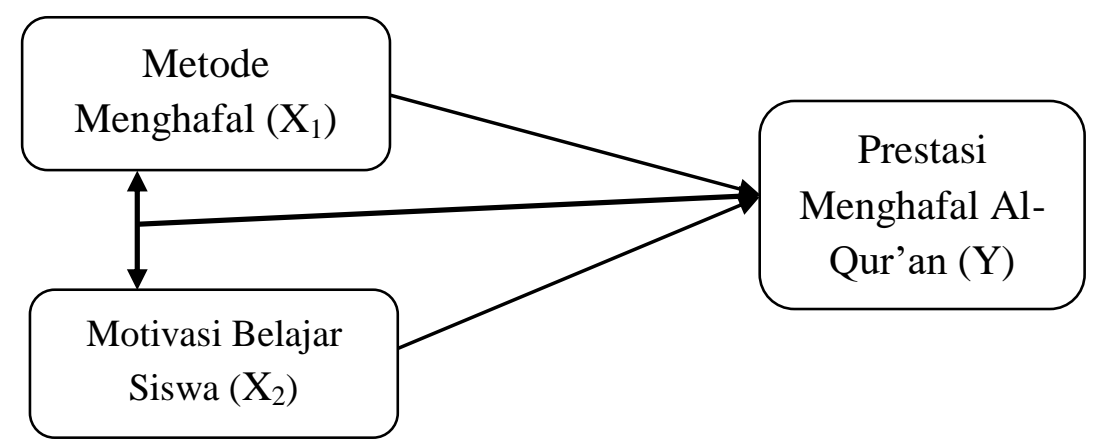

Gambar 2.1

Keterangan:

Kerangka Berpikir

\section{Hipotesis Statistik}

: metode menghafal

$\mathrm{X} 2$ : Motivasi belajar siswa

Y : prestasi menghafal Al-Qur'an

$\longrightarrow \quad=$ Regresi Ganda

$=$ Regresi Linear Sederhana

Hipotesis berasal dari bahasa Yunani yang mempunyai dua kata "hupo" (sementara) dan "thesis" (pernyataan atau teori). Jadi hipotesis adalah jawaban atau dugaan sementara yang harus duiji kebenarannya. ${ }^{21}$

Hipotesis adalah jawaban sementara dari rumusan masalah. ${ }^{22}$ Menurut Suharsini Arikunto hipotesis merupakan jawaban sementara terhadap rumusan masalah penelitian yang telah dinayatakan dalam bentuk pertanyaan. ${ }^{23}$ Bahwa hipotesis adalah sebuah taksiran atau referensi yang dirumuskan serta diterima

21 Syofian Seregar, Metode Penelitian Kuantitatif, Jakarta: Kencana Prenadamedia Group, Cet. II, 2014 hlm. 38 2003, hlm. 132

${ }^{22}$ Nursalam, Konsep Penerapan Metodologi Penelitian Ilmu, Jakarta: Salemba Medica,

${ }^{23}$ Suharsimi Arikunto, Prosedur Penelitian Suatu Pendekatan Praktek, Jakarta: Rineka Cipta, 2006, hlm. 64 
untuk sementara yang dapat menerangkan fakta-fakta yang diamati ataupun kondisi-kondisi yang diamati dan digunakan sebagai petunjuk untuk langkah penelitian selanjutnya.

Hipotesis statisika berupa simbol atau lambang para-meter statistika yang menggambarkan pernyataan tentang karakteristik populasi yang merupakan jawaban sementara atas pertanyaan penelitian. Pernyataan tersebut berbentuk proposisi sebagai hasil dari kerangka teoritik untuk hipotesis penelitian dan lingkarannya adalah hipotesis nol.

1. $\mathrm{H}_{0}=\rho_{\mathrm{y} .1} \leq 0$

$\mathrm{Ha}=\rho_{\mathrm{y} .1}>0$

$\mathrm{H}_{0}=$ Tidak terdapat pengaruh Metode Menghafal tehadap Prestasi Menghafal Al-Qur'an

$\mathrm{Ha}=$ Terdapat pengaruh Metode Menghafal tehadap Prestasi Menghafal Al-Qur'an

2. $\mathrm{H}_{0}=\rho_{\mathrm{y} .2} \leq 0$

$\mathrm{Ha}=\rho_{\mathrm{y} .2}>0$

$\mathrm{H}_{0}=$ Tidak terdapat hubungan Motivasi Belajar Siswa dengan Menghafal Al-Qur'an

$\mathrm{Ha}=$ Terdapat hubungan Motivasi Belajar Siswa dengan Menghafal AlQur'an

3. $\mathrm{H}_{0}=\rho_{\mathrm{y} \cdot 12} \leq 0$

$\mathrm{Ha}=\rho_{\mathrm{y} .12}>0$

$\mathrm{H}_{0}=$ Tidak terdapat pengaruh Metode Menghafal dan Motivasi Belajar Siswa secara bersama-sama dengan Menghafal Al-Qur'an.

$\mathrm{Ha}=$ Terdapat pengaruh Metode Menghafal dan Motivasi Belajar Siswa secara bersama-sama dengan Menghafal Al-Qur'an.

\section{Metode Penelitian}

Metode penelitian adalah cara yang digunakan oleh peneliti dalam mengumpulkan data penelitian. ${ }^{24}$ Dalam penelitian ini, metode yang digunakan adalah metode survei dengan teknik korelasional, penelitian untuk menggambarkan keadaan yang sedang berlangsung dan dianalisis secara kuantitatif dangan alat statistik mengenai hubungan dua variabel bebas yang terdiri dari Metode Menghafal $\left(\mathrm{X}_{1}\right)$, dan Motivasi Belajar Siswa $\left(\mathrm{X}_{2}\right)$, dengan variabel terikat yaitu Prestasi MenghafalAl-Qur'an (Y). Penelitian pada metode ini yaitu penelitian dengan mengetahui pengaruh satu variabel bebas terhadap variabel terikat (bivariat) atau pengaruh lebih dari dua variabel terhadap satu variabel terikat (multivariat) berdasarkan analisis regresi sederhana dan regresi ganda.

\section{Populasi dan Sampel}

1. Populasi

Populasi adalah wilayah generalisasi yang terdiri atas subjek/objek yang mempunyai karakteristik tertentu yang ditetapkan oleh peneliti untuk dipeljari danditarik kesimpulannya ${ }^{25}$. Dan Menurut Sugiono menyatakan bahwa "populasi adalah wilayah generalisasi yang terdiri atas obyek atau subjek yang mempunyai kualitas dan karakteristik tertentu yang ditetapkan oleh peneliti

\footnotetext{
${ }^{24}$ Etta Mamang Sangadji dan Sopiah, Metodelogi Penelitian "Pendekatan Praktis Dalam Penelitian, Yogyakarta: C.V Andi Offset, 2010, hlm. 154

${ }^{25}$ Suharsimi Arikunto, Prosedur Penelitian Suatu Pendekatan Peraktik, Jakarta: Rineka Cipta, 2002, hlm. 108
} 
untuk dipelajari dan kemudian ditarik kesimpulannya. ${ }^{26}$ Adapun populasi menurut Sutrisno Hadi, adalah keseluruhan objek-objek penelitian yang terdiri dari manusia, benda, tumbuh-tumbuhan dan peristiwa sebagai sumber data yang memiliki karakteristik tertentu dalam seluruh penelitian. ${ }^{27}$ Dari definisi tersebut dapat ditarik kesimpulan bahwa populasi adalah keseluruhan objek dan subjek penelitian yang memiliki karaktristik tertentu yang digunakan dalam sebuah penelitian.

Dalam penelitian kuantitatif populasi merupakan salah satu hal yang esensial dan perlu mendapat perhatian dengan seksama apabila peneliti ingin menyimpulkan suatu hasil yang dapat dipercaya dan tepat guna untuk daerah (area) atau objek penelitiannya. Jika peneliti ingin menyimpulkan sesuatu aspek tertentu, atau pada individu tertentu dalam area tertentu atau terhadap peristiwa tertentu, ia perlu menentukan terlebih dahulu apa batasan wilayah, ojek atau peristiwa yang akan diselidikinya. Wilayah, objek, atau individu yang diselidik memiliki karaktristk tertentu, yang akan mecerminkan atau memberi warna pada hasil penelitian. Secara umum ada beberapa karaktristik populasi yaitu antara lain:

a. Merupakan keseluruhan dari unit analisis sesuai dengan informasi yang akan diinginkan.

b. Dapat berupa manusia, hewan, tumbuh-tumbuhan, benda atau objek maupun kejadian yang terdapat dalam suatu area atau daerah tertentu yang telah ditetapkan.

c. Merupakan batasan (boundary) yang mempunyai sifat tertentu yang memungkinkan peneliti menarik kesimpulan dari keadaan tersebut.

d. Memberikan pedoman kepada apa atau siapa hasil penelitian itu dapat digeneralisasikan. ${ }^{28}$

Dari beberapa definisi diatas dapat ditarik kesimpulan bahwa populasi adalah keseluruhan objek dan subjek penelitian yang memiliki karaktristik tertentu yang digunakan dalam sebuah penelitian, dan adapun dalam penelitian ini yang digunakan sebagai populasi adalah seluruh siswa SMP IT Darul Qur'an Bogor dengan jumlah populasi 450 siswa pada tahun pelajaran 2016-2017.

Menurut Suharsimi Arikunto, apabila subyek yang diteliti kurang dari 100, lebih baik diambil semua sehingga penelitiannya merupakan penelitian populasi. Selanjutnya jika jumlahnya besar, dapat diambil antara 10\%$15 \%$ atau $20 \%-25 \%$ atau lebih. ${ }^{29}$

2. Sampel

Populasi dan sampel dalam suatu penelitian memeiliki peranan sentral dan menentukan, kedua istilah ini merupakan sebuah konsep yang memeiliki karaktristik dan sifat-sifat tertentu. Populasi merupakan keseluruhan aktribut yang dapat berupa masnusia, objek, atau kejadian yang menjadi fokus penelitian, sedangkan sampel adalah sebagaian dari objek, manusia, atau kejadian yang mewakili popilasi.

\footnotetext{
${ }^{26}$ Sugiyono, Metode Penelitian Kuantitatif Kualitatif Dan R dan D, Bandung: Alfabeta, Cet. Ke XVI, 2014, hlm. 119

${ }^{27}$ Sutrisno Hadi, Metodologi Research, Yogyakarta: Andi Offset, Cet. II, 1990, hlm. 3

${ }^{28}$ Muri Yusuf, Metode Penelitian Kuantitatif dan Penelitian Gabungan, Jakarta: Prenadamedia Group, 2014, hlm. 145-146

${ }^{29}$ Suharsimi Arikunto, Prosedur Penelitian Suatu Pendekatan Praktek, Jakarta: Rineka Cipta, 2002, hlm. 112
} 
Anas Sudijona mendefinisikan "sampel adalah himpunan kecil dari populasi yang seharusnya dipilih atau ditetapkan untuk keperluan analisis." 30 Sedangkan menurut Sukardi "sampel adalah jumlah populasi yang dipilih untuk sumber data". ${ }^{31}$

Toha mendefinisikan sampel penelitian ialah sebagian atau wakil populasi yang diteliti atau sebagian anggota populasi yang memberikan keterangan atau data yang diperlukan dalam suatu penelitian. Dengan kata lain, sampel adalah himpunan bagian dari populasi. ${ }^{32}$ Menurut Iskandar sampel adalah sebagian dari populasi yang diambil secara representatif atau mewakili populasi yang bersangkutan bagian kecil yang diamati. ${ }^{33}$

Salah satu syarat yang harus dipenuhi dalam pengambilan sampel adalah bahwa sampel harus diambil dari bagian populasi. Pengambilan sampel yang didasarkan atas ciri-ciri, sifat-sifat, atau karakteristik tertentu, yang merupakan ciri-ciri pokok populasi. Dan subyek yang diambil sebagai sampel benar-benar merupakan subyek yang paling banyak mengandung ciri-ciri yang terdapat pada populasi. ${ }^{34}$

Ciri-ciri sampel yang baik antara lain adalah:

a. Sampel dipilih dengan cara hati-hati; dengan menggunakan cara tertentu dengan benar.

b. Sampel harus mewakili populasi, sehingga gambara yang diberikan mewakili keseluruhan karaktristik yang terdapat dalam populasi.

c. Besarnya ukuran sampel hendaklah memperhatikan tingkat kesalahan sampel yang ditoleransi dan tingkat kepercayan yang dapat diterima secara statistik. $^{35}$

Penggunan sampel atau bukan populasi dalam penelitian bukan dimaksudkan untuk mengurangi ketelitian dan ketepatan hasil penyelidikan ataupun perediksi terhadap suatu masalah yang akan diselidiki.

Beberapa keuntungan menggunakan sampel:

a. Biaya penelitian berkurang, dikarenakan jumlah sumber data yang dikumpulkan lebih sedikit dari pada populasi.

b. Lebih cepat dalam pengumpulan dan pengolahan data.

c. Lebih akurat artinya dengan menggunakan sampel, maka jumlah personal yang akan diteliti lebih sedikit, sehingga peneliti dapat menggunakan tenaga yang lebih tinggi kualitasnya, dan latihan para petugas dapat diberikan lebih intensif sebelum kegiatan pengumpulan data dilakukan, hal yang demikian akan memberikan hasil yang lebik baik dan akurat.

d. Lebih luas ruang cakupan penelitian, jumlah responden lebih sedikit dibandingkan penelitian menggunakan populasi, dan hal ini dapat memberikan ruang cakupan yang lebih luas.

3. Teknik Pengambilan Sampel

\footnotetext{
${ }^{30}$ Anas Sudijono, Pengantar Setatistik Pendidikan, Jakarta: PT. Raja Grafindo Peersada, 1990, hlm. 26

${ }^{31}$ Sukardi, Metodologi Penelitian Pendidikan, Jakarta: BumiAksara, 2003, hlm. 54. 2004, hlm. 42

${ }^{32}$ Toha Anggoro, et al., Metode Penelitian, Jakarta: Pusat Penerbitan Universitas Terbuka,

${ }^{33}$ Iskandar, Metodologi Penelitian Pendidikan Dan Sosial, "Kuantitatif Dan Kualitatif", Jakarta: Gaung Persada Press, Cet. Ke II, 2009, hlm. 69

${ }^{34}$ Suharsimi Arikunto, Prosedur Penelitian Suatu Pendekatan Praktek, Jakarta: Rineka Cipta, 2002, hlm. 117

${ }^{35}$ Muri Yusuf, Metode Penelitian Kuantitatif dan Penelitian Gabungan, Jakarta: Prenadamedia Group, 2014, hlm.151
} 
Untuk menentukan sampel yang akan digunakan dalam penelitian, terdapat berbagai teknik sampeling yang akan digunakan, menurut Sugiyono, teknik sampling pada dasarnya dikelompokan menjadi dua, yaitu probability sampling dan nonprobability sampling. ${ }^{36}$

a. Probability Sampling adalah suatu sampel yang ditarik sedemikian rupa dimana suatu elemen atau unsur individu dari populasi, tidak didasarkan pada pertimbangan peribadi tetapi tergantung pada aplikasi kemungkinan (probabilitas) $^{37}$.Teknik ini meliputi:

1) Simpel Random Sampling

Dikatakan simpel (sederhana) karena cara pengambilan sampel dari semua anggota populasi dilakukan secara acak tampa memperhatikan strata yang ada dalam anggota populasi itu. Cara demikian dilakukan bila anggota populasi di angap homogen.

2) Proportionate Strafied Random Sampling

Teknik ini dilakukan bila populasi mempunyai anggota atau unsur yang tidak homogen dan berstrata secara proposional. Suatu organisasi yang memepunyai pegawai dari latar belakang pendidikan, maka populasi pegawai itu dikatakan berstrata.

3) Disproportionate Random Sampling

Teknik ini digunakan untuk menentukan jumlah sampel, bila populasi berstrat tetapi kurang proposional.

4) Cluster Sampling (Sampel Daerah)

Teknik sampling daerah digunakan untuk menentukan sampel bila obyek yang akan diteliti atau sumber data sangat luas, misalnya penduduk dari suatu Negara provinsi atau kabupaten. Untuk menentukan penduduk mana yang akan dijadikan sumber data, maka pengambilan sampelnya berdasarkan daerah dari populasi yang telah ditetapkan.

b. Nonprobability Sampling adalah teknik sampling yang tidak memberikan peluang atau kesempatan sama bagi setiap unsur atau anggota populasi untuk dipilih menjadi sampel. ${ }^{38}$ Teknik sampling ini meliputi:

1) Sampling Sistimatis

Sampling sisitimatis adalah teknik penentuan sampel berdasarkan urutan dari anggota populasi yang telah diberi nomer urut. Misalnya anggota populasi yang terdiri dari 100 orang, penggambilan sampel dapat dilakukan dengan nomer ganjil saja atau genap saja, atau kelipatan dari bilangan tertentu, misalanya kelipatan dari bilangan 5 . Untuk itu maka yang diambil sebagai sampel adalah 5, 10, 15 dan seterusnya sampe 100 .

2) Sampling kuota

Sampling kuota adalah teknik untuk menentukan sampel dari populasi yang mempunyai ciri-ciri tertentu sampai jumlah (kuota) yang di inginkan sebagai contoh, akan melakukan penlitian terhadap pegawai golongan II, dan penelitian dilakukan secara kelompok. Setelah jumlah sampel ditentukan umpama 100, dan jumlah anggota penelitian berjumlah 5 orang, maka setiap anggota peneliti dapat memilih sampel

\footnotetext{
${ }^{36}$ Sugiyono, Metode Penelitian Administrasi, Bandung: Alfabeta. 1993, hlm. 55-58

${ }^{37}$ Muhammad Nazir, Metode Penelitian,Jakarta: Ghalia Indonesia, 1988, hlm. 325

${ }^{38}$ Yaya Suryana, Metode Penelitian Manajemen Pendidikan, Bandung: Pustaka Setia,
} 2015, hlm. 253 
secara bebas sesuai dengan karaktristik yang ditentukan (golongan II) sebanyak 20 orang.

3) Sampling Aksidental

Sampeling aksidental adalah teknik penentuan sampel, berdasrkan kebetulan, yaitu siapa saja secara kebetulan bertemu dengan peneliti dapat digunakan sebagai sampel, bila dipandang orang yang kebetulan ditemui itu cocok sebagai sumber data.

4) Purposive Sampling

Purposive sampling adalah teknik penentuan sampel untuk tujuan tertentu saja. Misalanya akan melakukan penelitian tentang disiplin pegawai, maka sampel yang akan dipilih adalah orang yang ahli dalam kepegawean saja.

1) Sampel Jenuh

Sampel jenuh adalah teknik penentuan sampel bila semua anggota populasi digunakan sebagai sampel. Hal ini sering dilakukan bila jumalah populasi relatif kecil, kurang dari 30 orang. Istilah lain dari sampel jenuh ini adalah sensus, dimana semua anggota populasi dijadikan sampel.

2) Snowball Sampling

Snowball samling adalah teknik penentukan sampel yang mulamula jumlahnya kecil, kemudian sampel ini di suruh memeilih teman-temanya untuk dijadikan sampel begitu sterusnya, sehingga jumlah sampel semakin banyak. Ibarat bola salju yang menggelinding, makin lama makin besar.

Sampel adalah sebagian atau wakil populasi yang diteliti. Menurut Iskandar sampel adalah sebagian dari populasi yang diambil secara representatif atau mewakili populasi yang bersangkutan bagian kecil yang diamati. ${ }^{39}$ Ukuran sampel yang diambil menjadi persoalan penting karena karena jenis penelitian yang dilakukan adalah penelitian yang mengunakan analisis kuantitatif. 40

4. Ukuran sampel

Adapun sampel dalam penelitian ini adalah sebagian dari populasi siswa SMP IT Darul Quran (DQ) sebagai wakil dari populasi, karena anggota populasi dianggap tidak homogen dan berstrata proporsional karena siswa SMP IT Darul Quran (DQ) berlatar belakang yang berbeda-beda dari pintar sampai kurang pintar (bodoh), maka peneliti melakukan atau menentukan sampel meliputi strata pendidikan yang diambil cara acak (random), random sampling dalam menentukan pengambilan sampel. Untuk memudahkan dalam penelitian ini peneliti menghitung besaran sampel mengunakan teknik Slovin dengan batas kesalahan $5 \%(0,05)$. Adapun rumus slovin sebagai berikut: ${ }^{41}$

$$
\begin{aligned}
n= & \frac{N}{1+N d^{2}} \\
& \text { Keterangan } \\
\mathrm{n} \quad=\text { ukuran sampel atau jumlah responden } & \mathrm{N} \quad=\text { ukuran populasi atau jumlah populasi }
\end{aligned}
$$

\footnotetext{
${ }^{39}$ Iskandar, Metodologi Penelitian Pendidikan Dan Sosial, "Kuantitatif Dan Kualitatif", Jakarta: Gaung Persada Press, Cet. II, 2009, hlm. 69

${ }^{40}$ Deni Darmawan, Metode Penelitian Kuantitatif, Bandung : PT. Remaja Rosdakarya, 2013, hlm. 142 hlm. 34 .

${ }^{41}$ Syofian Siregar, Metode Penelitian Kuantitatif , Jakarta: Prenada Media Group, 2013,
} 
$\mathrm{d}=$ Error $(\%$ yang ditoleransi dengan ketidaktepatan pengunaan sampel sebagai penganti populasi)

Maka untuk mengetahui jumlah sampel penelitian, dilakukan perhitungan sebagai berikut:

$$
\begin{aligned}
& n=\frac{150}{150(0,05)^{2}+1} \quad n=\frac{150}{150(0,0025)+1} \quad n=\frac{150}{0,375+1}= \\
& n=\frac{150}{1,375}=109
\end{aligned}
$$

Adapun ukuran sampel yang diperlukan dalam penelitian ini, berdasarkan jumlah populasi penelitian sebagaimana telah dijelaskan di atas, yaitu 150 siswa kelas IX SMP IT Darul Quran, maka setelah dilakukan perhitungan dengan menggunakan rumus Slovin dengan margin error 0,05 atau 5\%, diperoleh ukuran sampel secara keseluruhan adalah 109 siswa kelas IX SMP IT Darul Quran, adapun alasan kenapa peneliti hanya mengambil sampel dari kelas IX saja, karena peneliti ingin mengetahui apakah kelas IX bisa mengimbangi anatara prestasi menghafal dengan pembelajaran di sekolah yang begitu padatnya sehingga peneliti tertarik ingin meneliti kelas IX tersebut. Adapun sebaran sampel setiap kelas secara proposional adalah sebagai mana terlihat pada tabel berikut:

Tabel 3.1

Jumlah siswa putra dan sampel penelitian

\begin{tabular}{|c|l|c|c|c|}
\hline No & Pendidikan & $\begin{array}{c}\text { Jumlah } \\
\text { siswa }\end{array}$ & $\begin{array}{c}\text { Ukuran } \\
\text { Sampel }\end{array}$ & $\begin{array}{c}\text { Jumlah } \\
\text { Sampel }\end{array}$ \\
\hline 1 & Kelas IX A & 30 & $\frac{30}{150} \times 109$ & 22 \\
\hline 2 & Kelas IX B & 30 & $\frac{30}{150} \times 109$ & 22 \\
\hline 3 & Kelas IX C & 30 & $\frac{30}{150} \times 109$ & 22 \\
\hline 4 & Kelas IX D & 30 & $\frac{30}{150} \times 109$ & 22 \\
\hline 5 & Kelas IX E & 30 & $\frac{30}{150} \times 109$ & 21 \\
\hline 6 & jumlah & 150 & & 109 \\
\hline
\end{tabular}

Sumber Data: Tata Usaha SMP IT Darul Quran Bogor 2017/2018

Pada umumnya data dapat diartikan sebagai suatu fakta yang bisa digambarkan dengan kode, simbol, angka dan lain-lain. Data juga diartikan sebagai hasil pencatatan peneliti, baik itu berupa fakta ataupun angka. ${ }^{43}$ Selain itu data juga diartikan sebagai hasil pengukuran atau observasi yang sudah dicatat guna suatu keperluan tertentu.

Berdasarkan sifatnya data dapat dikelompokan kedalam dua bagian yaitu data kuantitatif dan kualitataif, data kuantitatif adalah data yang berbentuk angka atau bilangan yang dapat diolah atau dianalisis menggunakan teknik perhitungan matematika atau statistik. Adapun data kualitatif adalah

\footnotetext{
${ }^{42}$ Asep Muliana, Tata Usaha SMP IT Darul Quran Bogor 2017-2018

${ }^{43}$ Suharsimi Arikunto, Prosedur Penelitian Suatu Pendekatan Praktek, Jakarta: Rineka Cipta 2006, hlm.118

${ }^{44}$ Soeratno dan Lincolin Arsyad, Metodologi Penelitian untuk Ekonomi dan Bisnis, Yokyakrta: UPP AMP YKPN, 2003, hlm. 72-73
} 
data yang berhubungan dengan kategorisasi atau karaktristik dalam bentuk sifat bukan angka yang tidak dapat diukur besar kecilnya.

Sebelum kita membahas mengenai jenis-jenis data kualitatif dan kuantitatif, maka perlu diketahui bahwa yang dimaksud dengan data adalah sesuatu yang dibutuhkan dalam sebuah penelitian yang dilakukan dengan menggunakan parameter tertentu. Data dalam penelitian kualitatif biasanya tidak dituangkan dalam bentuk angka, namun lebih cendrung pada bentuk deskriptif, gambar, ataupun bagan yang di dasarkan pada fakta yang terjadi dalam penelitian.

\section{Deskripsi Data Dan Uji Hipotesis}

Berdasarkan hasil pengujian hipotesis sebagaimana telah diuaraikan di atas, maka secara keseluruhan temuan dalam penelitian ini, dapat dibahas dengan cara mengkonfirmasi terhadap teori-teori yang sudah ada, sebagaimana telah dikemukakan pada Bab II, jadi dalam pembahasan penelitian ini akan diuraikan hasil temuan penelitian dan menguraikan hasil uji hipotesis berserta teori-teori yang telah diungkapkan sebelumnya.

Dari hasil analisis deskriptif variabel penelitian variabel prestasi menghafal Al-Qur'an dilihat dari skor rata-rata metode menghafal yaitu 84,53 atau sama dengan 84,53: $100 \times 100 \%=84,53 \%$ dari skor idealnya yaitu 100 . Pada kreteria taraf tinggi sebesar $84,53 \%$, hal ini dapat ditafsirkan bahwa para Siswa SMP IT pondok pesantren Darul Qur'an telah meraih prestasi menghafal Al-Qur'an dengan taraf tinggi, untuk variabel metode menghafal dilihat dari skor rata-rata metode menghafal 90,28 atau sama dengan 90,28:130 X 100\%= $69,45 \%$ dari skor idealnya yaitu. Pada kreteria taraf sedang sebesar 69,45\%, hal ini dapat ditafsirkan bahwa pimpinan pesantren telah menerapkan metode menghafal yang baik dan sesuai dengan situasi sehingga mampu mempengaruhi para siswa dalam menghafal Al-Qur'an. Sedangkan variabel motivasi belajar siswa dilihat dari skor skor rata-rata motivasi belajar siswa yaitu 101,63 atau sama dengan 101,63: 137 X 100\% =74,18 \% dari skor idealnya yaitu 137. pada taraf cukup tinggi sebesar 72,36 hal ini menunjukkan bahwa siswa SMP IT Darul Qur'an telah memiliki motivasi yang baik dalam belajar dan melaksanakan aturan yang telah ditetapkan pondok pesantren Darul Qur'an.

Sedangkan hasil uji persyaratan hipotesis penelitian telah terpenuhi, yakni uji linieritas persamaan regresi $\mathrm{Y}$ atas $\mathrm{X}_{1}$ menunjukkan nilai $\mathrm{P}$ Sig $=0,426>0,05$ $(5 \%)$ atau $\mathrm{F}_{\text {hitung }}=1,04$ dan $\mathrm{F}_{\text {tabel }}$ dengan $\mathrm{dk}$ pembilang $37 \mathrm{dan} \mathrm{dk}$ penyebut 70 dan pada taraf kepercayaan (signifikansi) $\alpha=0,05$ adalah 1.57 ( $\mathrm{F}_{\text {hitung }}$ $1,04<\mathrm{F}_{\text {tabel }}$ 1,57), yang berarti $\mathrm{Ho}$ diterima dan $\mathrm{H}_{1}$ ditolak. Dengan demikian, maka dapat di interpretasikan atau ditafsirkan bahwa persyaratan linearitas terpenuhi atau model persamaan regresi $\hat{\mathrm{Y}}$ atas $\mathrm{X}_{1}$ adalah linear dan persamaan regresi $\mathrm{Y}$ atas $\mathrm{X}_{2}$ menunjukkan nilai $\mathrm{P}$ Sig $=0,197>0,05(5 \%)$ atau $F_{\text {hitung }}=1,26$ dan $F_{\text {tabel }}$ dengan dk pembilang 46 dan dk penyebut 61 dan pada taraf kepercayaan (signifikansi) $\alpha=0,05$ adalah $1,57\left(\mathrm{~F}_{\text {hitung }} 0.671<\right.$ $\left.F_{\text {tabel }} 1,56\right)$, yang berarti Ho diterima dan $\mathrm{H}_{\mathrm{i}}$ ditolak. Dengan demikian, maka dapat di interpretasikan atau ditafsirkan bahwa persyaratan linearitas terpenuhi atau model persamaan regresi $\hat{\mathrm{Y}}$ atas $\mathrm{X}_{2}$ adalah linear. $\hat{\mathrm{Y}}$ atas $\mathrm{X}_{1}$ dan $\mathrm{X}_{2}$ menunjukkan Asymp. Sig (2-tailed) atau nilai $\mathrm{P}=0,200>0,05(5 \%)$ atau $\mathrm{Z}_{\text {hitung }} 0,045$ dan $\mathrm{Z}_{\text {tabel }}$ pada taraf kepercayaan atau signifikansi $\alpha=0,05$ adalah 1,960 ( $\left.\mathrm{Z}_{\text {hitung }} 0.045<\mathrm{Z}_{\text {tabel }} 1,960\right)$, yang berarti Ho diterima dan $\mathrm{H}_{1}$ ditolak. Dengan demikian dapat diinterpretasikan atau ditafsirkan bahwa persyaratan 
normalitas distribusi galat taksiran terpenuhi dengan kata lain galat taksiran persamaan regresi $\hat{\mathrm{Y}}$ atas $\mathrm{X}_{1} \operatorname{dan}_{2}$ adalah berdistribusi normal.

\section{KESIMPULAN}

Berdasarkan analisis dan pembahasan dari data tentang penilaian responden terhadap pengaruh metode menghafal, motivasi belajar siswa terhadap prestasi menghafal Al-Qur'an di SMP IT Darul Qur'an Bogor, dapat disimpulkan, yaitu:

1. Hipotesa pertama ditrima karena teruji terdapat pengaruh yang positif dan signifikan antara metode menghafal dengan prestasi menghafal Al-Qur'an siswa SMP IT Darul Qur'an. Maka hal ini dapat ditunjukan dengan harga koefisien korelasi atau kekuatan pengaruh $\left(\mathrm{ry}_{1}\right)$ sebesar 0,458 pada tingkat kepercayaan $99 \%(\alpha=0,01)$ yang berarti pasangan data variabel metode menghafal $\left(\mathrm{X}_{1}\right)$ dan variabel prestasi menghafal Al-Qur'an (Y) memiliki korelasi linier positif yng kuat karena nilai ry.1 mendekati +1 (positif satu), harga koefisisen determinasi atau besarnya pengaruh $R$ square sebesar 0,009 yang berarti bahwa metode menghafal dapat memberikan pengaruh sebesar $0,9 \%$ terhadap prestasi menghafal Al-Qur'an sedangkan sisanya 99,1 (100\% $-0,9 \%=99,1 \%$ ) ditentukan oleh faktor-faktor yang lainnya. Persamaan garis regresinya $\hat{\mathrm{Y}}=87,325+0,001 \mathrm{X}_{1}$. Dari hasil analisis diperoleh $\mathrm{t}_{\text {hit }}=0,027 \mathrm{dan}$ p-value $=0,00<0,05$ atau $\mathrm{H}_{\mathrm{o}}$ ditolak. Dengan demikian, metode menghafal berpengaruh positif terhadap prestasi menghafal Al-Qur'an. Memperhatikan hasil analisis regresi diata, menunjukkan persamaan regresi (unstandardized coefficients $B) \hat{\mathrm{Y}}=87,325+0,001 \mathrm{X}_{1}$, berarti bahwa setiap peningkatan satu unit metode menghafal akan mempengaruhi peningkatan skor prestasi menghafal Al-Qur'an 0,027.

2. Hipotesa kedua ditrima karena teruji terdapat pengaruh yang positif dan signifikan antara motivasi belajar siswa dengan prestasi menghafal Al-Qur'an siswa SMP IT Darul Qur'an. Maka hal ini dapat ditunjukan dengan harga koefisien korelasi atau kekuatan pengaruh $\left(\mathrm{ry}_{1}\right)$ sebesar $0,112^{\mathrm{a}}$ pada tarap kepercayaan $\alpha=0,01$ yang berarti pasangan data variabel motivasi belajar siswa $\left(\mathrm{X}_{2}\right)$ dan variabel prestasi menghafal menghafal Al-Qur'an (Y) memiliki korelasi linier positif yang lemah karna nilai ry.1 tidak mendekati +1 (positif satu), harga koefisisen determinasi atau besarnya pengaruh $R$ square sebesar 0,012 Hal ini menunjukan bahwa motivasi belajar siswa $\left(\mathrm{X}_{2}\right)$ memberikan pengaruh terhadap prestasi menghafal Al-Qur'an (Y) sebesar 1,2\% sedangkan sisanya $98,8 \%(100 \%-1,2=98,8 \%)$ ditentukan oleh faktor-faktor yang lainnya. persamaan garis regresi di peroleh dari baris regression yaitu $\mathrm{F}_{\text {hit }}$ $=1,354$ dan p-value $0,00<0,05$ atau $\mathrm{H}_{\mathrm{o}}$ diterima. Dengan demikin regresi $\mathrm{Y}$ atas $\mathrm{X}_{2}$ adalah tidak signifikansi atau motivasi belajar siswa tidak berpengaruh terhadap prestasi menghafal Al-Qur'an. Memperhatikan hasil analisis regresi sederhana, menunjukkan persamaan regresi (unstandardized coefficients $B$ ) $\hat{Y}$ $=81,226+0,060 \mathrm{X}_{2}$, yang berarti bahwa setiap penurunan satu unit motivasi belajar siswa akan mempengaruhi penurunan skor prestasi menghafal AlQur'an sebesar 0,060.

3. Hipotesa ketiga ditrima karena teruji terdapat pengaruh yang positif dan signifikan antara metode menghafal dan motivasi belajar siswa secara bersama-sama dengan prestasi menghafal Al-Qur'an siswa. Hal ini dapat ditunjukkan SMP IT Darul Qur'an Bogor dengan harga koefisien korelasi atau kekeuatan pengaruah $\left(R y_{\cdot 1.2}\right)$ sebesar $0,112^{\mathrm{a}}$ dan 0,125 Dengan demikian, 
maka Ho ditolak dan Hi diterima, yang berarti bahwa terdapat pengaruh positif dan signifikan metode menghafal dan Motivasi belajar siswa terhadap prestasi menghafal Al-Qur'an. Uji signifikansi koefisien korelasi ganda di peroleh hasil dari tabel Model Summary di atas, terlihat pada baris pertama bahwa koefisien korelasi ganda $\left(\mathrm{R}_{\mathbf{1 . 2}}\right)=0,671$, serta $\mathrm{p}$-value $0,000<0,05$ atau $\mathrm{H}_{\mathrm{o}}$ ditolak. Dengan demikian, koefisien korelasi ganda antara $\mathrm{X}_{1}$ dan $\mathrm{X}_{2}$ dengan $\mathrm{Y}$ adalah berarti atau signifikan. Adapun koefisien determinasi di tunjukkan oleh $\mathrm{R}^{2}(R$ square)sebesar 0,125 (adalah pengkuadratan dari koefisien korelasi atau $0,671 \mathrm{x} 0,671=0,125)$ yang mengandung makna bahwa $12,5 \%$ variabilitas variabel prestasi menghafal Al-Qur'an dapat dijelaskan oleh metode menghafal dan motivasi belajar siswa. Hal ini dapat disimpulkan bahwa metode menghafal $\left(\mathrm{X}_{1}\right)$ dan motivasi belajar siswa $\left(\mathrm{X}_{2}\right)$ secara bersama-sama memberikan pengaruh terhadap prestasi menghafal $\mathrm{Al}$ Qur'an (Y) sebesar 12,5\% sedangkan sisanya 87,5\% $(100 \%-12,5 \%=87,5$ $\%)$ ditentukan oleh faktor-faktor yang lainnya. persamaan regresi linear ganda (unstandardized coefficients $B$ ) $\hat{\mathrm{Y}}=81,319+-0,001 \mathrm{X}_{1}+0,060 \mathrm{X}_{2}$. yang berarti bahwa setiap peningkatan satu unit metode menghafal dan motivasi belajar siswa akan mempengaruhi peningkatan skor prestasi menghafal Al-Qur'an sebesar 81,378 .

\section{DAFTAR PUSTAKA}

Abidin, Ahmad Zainal, Kilat dan Mudah Hafal juz Amma, Yogyakarta: Sabil, 2015

Abta, Asyhari, "Motivasi dan Metode Siswa Siswi MA Ali Makuk Pondok

Pesantren Krapyak Yogyakarta dalam Menghafal Al-Qur'an", Tesis, Surabaya: Pasca Sarjana Universitas Sunan Giri, 2006

Aldelfer, Clayton, Existence, Relatednes, and Growth, New York: Free Press 1972.

Alfianika, Ninit, Metode Penelitian Bahasa Indonesia, Yogyakarta: Deepublish, 2016.

Amanah, Pengantar Ilmu Al-Qur'an \&Tafsir, Semarang : As-Syifa,1991.

Anggoro, Toha, et al., Metode Penelitian, Jakarta: Pusat Penerbitan Universitas Terbuka, 2004.

Anwar, Desy, Kamus Lengkap Bahasa Indonesia, Surabaya: Amelia, Cet I, 2003.

Anwar, Moch Idochi, Pengaruh Ilmu Organisasi Sekolah dan Kepuasan Kerja Terhadap Performance Kerja Guru, Bandung: Tesis, FPS IKIP Bandung, 1984.

Arif, Armai, Pengantar Ilmu dan Metodologi Pendidikan Islam, Jakarta: Ciputat Press, 2002.

Arikunto, Suharsimi, Penelitian Tindakan Kelas, Jakarta: Bumi Aksara, 2008.

------. Prosedur Penelitian Suatu Pendekatan Peraktik, Jakarta: Rineka Cipta, 2002.

Prosedur Penelitian Suatu Pendekatan Praktek, Jakarta: Rineka Cipta, 2006.

prosedur Penelitian Suatu Pendekatan Praktik, Jakarta: Rineka Cipta, 1998.

------. Manajemen Penelitian, Jakarta: Rineka Cipta, 2000.

Asyqar, M. Sulaiman Al, Al Wadhih Fi Ushulil Fiqih, Oman: Dar'an Nafa'is.

Azwar, Syarifudin, Metode Penelitian, Yokyakarta: Pustaka Belajar, 2007. 
Badwilan, Ahmad Salim, Panduan Cepat Menghafal Al-Qur'an, Jogjakarta: Diva Press, 2009.

Baharuddin, Psikologi Pendidikan:Refleksi Teoritis Terhadap Penomena, Jogjakarta: Ar-Ruzz Media, 2010.

------. Teori Belajar dan Pembelajaran, Jogjakarta: AR-Ruzz Media, 2010.

Baidhowi, Antropolgi Al-Qur'an, Yogyakarta: Lkis, 2009.

Baqi, Muhammad Fuadi Abdul, Al-lu'lu' Wal Marjan, Alih Bahsa: Muslich Shobir, Semarang : Al-Ridh, 1993.

Buchori M, Psikologi Pendidikan, Jakarta: Rineka Cipta, 1991.

D.H Schunk \& Zimmerman, B.J (Eds), Self Regulated Learning: From: Teaching to Self Reflective Practice, New York: The Guilford Press, 1988.

Darmawan, Deni, Metode Penelitian Kuantitatif, Bandung : PT. Remaja Rosdakarya, 2013.

Denim, Sudarwan, Motivasi Kepemimpinan Dan Efektifitas Kelompok, Jakarta: Rineka Cipta, 2004.

Departemen Pendidikan dan Kebudayaan, Kamus Besar Bahasa Indonesia, Jakarta: Balai Pustaka, 2005.

Depdiknas, Kamus Besar Bahasa Indonesia,Jakarta, 2012.

Djaali, Psikologi Pendidikan, Jakarta:PT Bumi Aksara, Cet. II, 2008.

Djamarah, Syaiful Bahri, Rahasia Sukses Belajar, Jakarta: PT Asdi Maha Satya, 2002.

------. Konsep dan Makna Pembelajaran, Bandung: Alfabeta, 2003.

------. Psikologi belajar, Jakarta: Rineka Cipta, 2002.

------. Psikologi Belajar, Rineka Cipta, Edisi Revisi, Cet III, 2011.

Effendi, Yusuf, "Nilai dan Tanggungjawab dalam metode pembelajaran tahfizh siswa MAK An-Nur di PP An-Nur Ngrukem Bantul, Tesis Yogyakarta: Prodi Pendidikan Islam Konsentrasi Pendidikan Qur'an Hadits UIN Pasca Sarjana, 2011

Farid Poniman, et.al., Kubik Leadership, Solusi Esensial Meraih Sukses Dan Kemuliaan Hidup, Jakarta: Hikmah, 2006.

Al-Ghozali, Imam, Aplikasi Analisis Multivariate dengan Program IBM SPSS 19, Semarang: Badan Penerbit Universitas Diponegoro, 2011.

Hadi, Sutrisno, Metodologi Research, Yogyakarta: Andi Offset, Cet. II, 1990 